\author{
Andrzej Kowalczyk \\ Uniwersytet Warszawski \\ Zakład Geografii Turyzmu i Rekreacji \\ 00-927 Warszawa, ul. Krakowskie Przedmieście 30 \\ tel. 048225521512 \\ akowalczyk@uw.edu.pl
}

\section{SYSTEMY HOTELOWE - ICH POCZĄTKI I EWOLUCJA}

Zarys treści: W światowym hotelarstwie rola systemów hotelowych jest coraz większa. O ile ich geneza związana jest $\mathrm{z}$ wejściem gospodarki kapitalistycznej w fazę kapitalizmu monopolistycznego, o tyle ich obecny rozwój należy wiązać ze zjawiskiem globalizacji. W historii systemów hotelowych można wydzielić kilka zasadniczych etapów, których początek i koniec związane są z kluczowymi wydarzeniami nie tylko dla hotelarstwa, ale również dla całej gospodarki turystycznej.

Słowa kluczowe: system hotelowy, typy hoteli, globalizacja, konsolidacja rynku.

\section{WPROWADZENIE}

Znaczna część hoteli na świecie należy do kilkudziesięciu tzw. łańcuchów czy systemów o zasięgu obejmującym często niemal wszystkie kontynenty. Jak uważa ForMICA (1996), zgodnie z teorią business life-cycle, ich ekspansja jest następstwem osiagnięcia przez sektor hotelarski fazy, w której dalszy rozwój możliwy jest nie tylko poprzez konsolidację działających dotąd $w$ rozproszeniu hoteli, ale również poprzez opanowywanie przez nie nowych rynków. Tak więc rozwój systemów hotelowych można uważać za przejaw znalezienia się sektora usług hotelarskich nie tyle w fazie monopolizacji, co raczej globalizacji.

\section{ETAP PIERWSZY (PRZED 1950 ROKIEM)}

Według MiLEWSKIEJ i WŁodarCZYKa (2005), za początki rozwoju systemów hotelowych na świecie można przyjąć rok 1907, kiedy to Ellsworth M. Statler (1863-1928) otworzył w Buffalo (Stany

\section{HOTEL CHAINS: AN APPROACH TO THEIR ORIGIN AND EVOLUTION}

\begin{abstract}
In the world hotel industry the role of hotel chains is constantly growing. Although their origin relates to when the capitalist economy entered the stage of monopoly capitalism, their present development is connected to the phenomenon of globalization. The history of hotel chains can be divided into several stages whose beginnings and ends are marked by key events, essential not only for the hotel industry but also for the whole tourism economy.
\end{abstract}

Key words: hotel chain, types of hotel, globalization, market consolidation.

\section{INTRODUCTION}

A large number of the world's hotels belong to chains or chains which themselves often encompass nearly all the continents. FORMICA (1996) claims that, according to business life-cycle theory, their expansion has resulted from the fact that the hotel sector has reached a phase in which further development is possible not only through consolidation, but also through conquering new markets. Therefore, the development of hotel chains can be regarded as a sign that the hotel sector is entering the phase of globalization rather than simply monopolization.

\section{PHASE I (BEFORE 1950)}

According to MILEWSKA \& WŁODARCZYK (2005), the development of hotel chains began in 1907 when Ellsworth M. Statler (1863-1928) opened a hotel in Buffalo 
Zjednoczone, stan Nowy Jork) hotel, który - jak się wkrótce okazało - dał początek późniejszemu systemowi Hotels Statler Company, Inc. O ile Ellswortha M. Statlera należy uważać za człowieka, który założył pierwszy system hotelowy, o tyle Conrad N. Hilton stworzył podwaliny systemu, który nie tylko istnieje do chwili obecnej, ale jednocześnie był i jest jednym z czołowych systemów hotelowych świata.

Pierwszą inwestycją C. N. Hiltona był hotel w Cisco („Mobley Hotel”) w stanie Teksas. Został on zakupiony w 1919 r., a więc wówczas, gdy działający we wschodniej części Stanów Zjednoczonych M. Statler dysponował już kilkoma obiektami ${ }^{1}$. Jednak fakt, iż pierwsza inwestycja C. N. Hiltona powstała w Teksasie - stanie przeżywającym w tym czasie wyjątkową koniunkturę gospodarczą - sprawił, że hotel w Cisco szybko zaczął przynosić zyski, co pozwoliło C. N. Hiltonowi otworzyć kolejne obiekty. Już wkrótce C. N. Hilton nabył (wspólnie ze swoim przyjacielem) hotel w Forth Worth, a w 1924 r. C. N. Hilton i W. R. Irwing utworzyli spółkę Hilton Hotel, Inc. Do roku 1935 Hilton Hotel, Inc. działał tylko w Teksasie. Pierwszym obiektem poza Teksasem był zakupiony w 1938 r. hotel „The Sir Francis Drake” w San Francisco (stan Kalifornia). Trwające od kilkunastu lat pasmo sukcesów sprawiło, że w 1946 r. na giełdzie nowojorskiej zadebiutowała firma o nazwie Hilton Hotels Corp. Wydarzenie to nie zahamowało jednak dalszej ekspansji systemu: w roku 1948 w ramach Hilton Hotels Corp. uruchomiono własny system rezerwacji pokoi (Inter-Hilton Hotel Reservation System), a w 1949 r. w San Juan (Portoryko) otwarto pierwszy hotel poza granicami Stanów Zjednoczonych - „The Caribe Hilton”2.

Jednak zanim Ellsworth M. Statler otworzył hotel „Buffalo Statler”, a Conrad N. Hilton kupił „Mobley Hotel”, w sąsiedniej Kanadzie działały już hotele należące do linii kolejowej Canadian Pacific Railway (CPR). Inicjatorem ich budowy był prezydent kompanii, William Cornelius Van Horne, który jeszcze w XIX w. zaczął realizować program budowy hoteli w pobliżu stacji Canadian Pacific Railway. Ideą, jaka przyświecała W. C. Van Horne'owi było sprawienie, aby dziewicze tereny w Górach Skalistych, obfitujące nie tylko w piękne widoki, ale i liczne źródła mineralne, mogły zaczać być odwiedzane przez turystów korzystających z pociagów Canadian Pacific Railway i zatrzymujących się w należących do linii kolejowej hotelach. Jednak dopiero zbudowanie w roku 1888 w Banff dużego „Banff Springs Hotel” spra-
(New York State, USA) which, as it soon turned out, was to start the Hotel Statler Company, Inc. chain. If Ellsworth M. Statler should be credited as the originator of the first hotel chain, Conrad N. Hilton was the one who put the chain on a footing which has existed until the present day, while simultaneously his chain has become one of the world's leading hotel chains.

Hilton's first investment was the Mobley a hotel in Cisco, Texas and was purchased in 1919, i.e. at a time when Statler already owned several hotels in the eastern part of the United States ${ }^{1}$. However, the fact that Hilton's first hotel was opened in Texas - a state which at that time was flourishing economically made it possible for him to profit from it very quickly, and consequently open new hotels. Soon Hilton (together with a friend) bought a hotel in Forth Worth, and in 1924 Hilton and Irving established Hilton Hotel, Inc. Until 1935 they operated only in Texas with the first hotel outside being the Sir Francis Drake in San Francisco (California), bought in 1938. Several years of success resulted in a company called Hilton Hotels Corp. entering the New York Stock Exchange. This event enabled further expansion of the chain: in 1948, as part of Hilton Hotels Corp., the Inter-Hilton Hotel Reservation System was started, and in 1949 in San Juan (Puerto Rico) the first hotel outside the USA was opened - the Caribe Hilton ${ }^{2}$.

But before Ellsworth M. Statler opened the Buffalo Statler and Conrad N. Hilton had bought the Mobley Hotel, hotels belonging to the Canadian Pacific Railway $(C P R)$ were already operating in Canada. Their construction was initiated by the company president, William Cornelius Van Horne, who had begun building hotels near railway stations as early as the $19^{\text {th }} \mathrm{c}$. His idea was to attract tourists to travel by the Canadian Pacific Railway to the virgin Rocky Mountains, which offered not only breathtaking views but also mineral springs, to stay in his hotels. However, his idea only started to bring in substantial profits after the large Banff 
wiło, że pomysł W. C. Van Horne'a zaczał przynosić duże dochody, czego dowodem było, iż w następnych latach hotele CPR (później włączone w skład systemu Canadian Pacific Hotels) zaczęły również powstawać w innych częściach Kanady.

Chociaż zarówno Ellsworth M. Statler, jak i Conrad N. Hilton oraz William Cornelius Van Horne pochodzili z Ameryki Północnej ${ }^{3}$, również w Europie i w Japonii zaczęły powstawać w tym okresie pierwsze systemy hotelowe. Część $\mathrm{z}$ nich - np. w Japonii - była zakładana przez przedsiębiorstwa zajmujące się transportem kolejowym. W tym czasie w Związku Radzieckim (oraz w niektórych krajach Ameryki Łacińskiej - np. Meksyku) pojawily się również pierwsze państwowe sieci hotelowe, które jednak trudno uznać za systemy hotelowe we właściwym tego słowa znaczeniu.

\section{ETAP DRUGI (LATA 1950-1970)}

Trudno w sposób jednoznaczny określić moment przejścia $\mathrm{z}$ etapu pierwszego do etapu drugiego W historii światowych systemów hotelowych. Mogło to mieć miejsce zarówno tuż przed II wojną światową (np. z chwilą powstania Travelodge Hotels, Inc.), w pierwszych latach po jej zakończeniu (np. w związku $\mathrm{z}$ powstaniem Inter-Continental Hotels \& Resorts w 1946 r.), ale też w sierpniu 1952 r., tzn. z momentem otwarcia w Memphis (stan Tennessee) hotelu „Holiday Inn”. Wiadomo jedynie, że zjawiskiem, które należy uznać za początek drugiego etapu w historii systemów hotelowych było pojawienie się przedsiębiorstw specjalizujących się $w$ relatywnie tanich hotelach dla klientów korzystających z samochodów. Tego typu hotele - można je uznać za poprzedzające hotele budżetowe i ekonomiczne - zaczęły masowo poWstawać w Stanach Zjednoczonych i Kanadzie już przed II wojną światową, ale dopiero na przełomie lat 40. i 50. XX w. pojawiły się duże systemy specjalizujące się w takich obiektach.

W odróżnieniu od hoteli wchodzących w skład pierwszych systemów hotelowych, obiekty należące do systemów zorientowanych przede wszystkim na obsługę gości podróżujących samochodami były lokalizowane głównie w zewnętrznych strefach dużych aglomeracji miejskich, ale również w mniejszych miejscowościach lub wręcz poza nimi. Ich Wspólną cechą było jednak położenie przy szosach (często przy - powstających w tym czasie - pierwszych autostradach), w pobliżu węzłów drogowych, przy stacjach benzynowych itp. Do syste-
Springs Hotel was built in 1888. In the following years CPR hotels (later incorporated into the Canadian Pacific Hotels chain) were opened in other parts of Canada.

Although Ellsworth M. Statler, Conrad N. Hilton and William Cornelius Van Horne all came from North America ${ }^{3}$, hotel chains started to appear in Europe and Japan at that time, and some (e.g. in Japan) had been set up by railway transport enterprises. In the Soviet Union (and some Latin American countries, e.g. Mexico) the first state hotel networks appeared, but they can hardly be regarded as hotel chains in the precise sense of the term.

\section{PHASE II (1950-70)}

It is difficult to pinpoint the exact moment of transition from phases I to II in the history of hotel chains. It could have been just before World War II broke out (e.g. when Travelodge Hotels Inc. was created), in the first years after it ended (e.g. when InterContinental Hotels \& Resorts began in 1946), or in August 1952, the year when a Holiday Inn was opened in Memphis (Tennessee). It is certain, however that the phenomenon which marked the beginning of the second phase in the history of hotel chains was the appearance of enterprises specializing in relatively cheap hotels for drivers. Hotels of this type - and they can be considered the precursors of budget and economy hotels - had started to appear on a massive scale in the United States and Canada before World War II, but only in the late 1940s did large chains specializing in this kind of hotel appear.

In contrast to those hotels which constituted the first hotel chains, those oriented mostly towards guests travelling by car were usually located in the outer zones of large urban conurbations, as well as in smaller towns or even outside either of them. What they had in common was a location by a road (often by the motorway-type roads which were being 
mów dysponujących tego rodzaju obiektami należały m.in.: obecny Best Western International, Inc. (1946 r. - wówczas Best Western Motel), wspomniany Travelodge Hotels, Inc., a także powstałe nieco później (1954 r.) systemy Holiday Inns of America Corp. oraz Howard Johnson Co.

Jednak w drugim okresie rozwoju systemów hotelowych pojawiło się również inne interesujące zjawisko. Otóż równolegle do systemów zorientowanych na przyjmowanie w swoich hotelach gości poruszających się samochodami pojawiły się systemy powstające $\mathrm{z}$ inicjatywy dużych linii lotniczych. Pierwszym takim systemem był wspomniany Inter-Continental Hotels \& Resorts, który powstał w 1946 r. z inspiracji linii PanAmerican World Airways. Główną cechą wyróżniającą tego typu systemy było to, iż z reguły dysponowały dużymi, wysokiej kategorii (5 lub 4 gwiazdki) obiektami, które byly otwierane w miastach (często stolicach państw lub innych dużych aglomeracjach), dokąd docierały samoloty danej linii. Tak było w przypadku wspomnianego Inter-Continental Hotels \& Resorts, którego pierwszym obiektem był otwarty w 1947 r. hotel „Grande Belem" w mieście Belem (Brazylia).

Ponieważ poczynając od przełomu lat 50. i 60 . XX w. możemy zaobserwować szybki rozwój cywilnego transportu lotniczego (co w dużej mierze było związane $\mathrm{z}$ pojawieniem się samolotów pasażerskich wyposażonych w silniki odrzutowe), w następnej dekadzie klientami linii lotniczych stały się nie tylko osoby bogate, ale i średniozamożne. To z kolei sprawiło, iż pojawił się popyt na usługi noclegowe w hotelach niższych kategorii. Dlatego też pod koniec dekady lat 60 . coraz więcej hoteli zorientowanych na turystów podróżujących samolotami zaczynało świadczyć usługi typowe dla hoteli ekonomicznych. Oznacza to, iż zaczęłły one być budowane nie tylko w największych aglomeracjach miejskich świata (obsługiwanych przez główne linie lotnicze świata), ale również w mniejszych ośrodkach, często atrakcyjnych pod względem turystycznym, ale czasami w ,zwykłych" miastach o rozwiniętych funkcjach przemysłowych oraz usługowo-administracyjnych.

Innym bardzo ważnym zjawiskiem, jakie pojawiło się już na początku lat 50 . XX w., było powstanie systemów hotelowych specjalizujących się w hotelach pobytowych, związanych $\mathrm{z}$ wypoczynkiem urlopowym. Pierwszym systemem tego typu stał się Club Méditerranée (Francja). Jego początki sięgaja jeszcze 1949 r., kiedy to Gérard Blitz zorganizował dla swoich znajomych urlop w namio- then built), and near road junctions, petrol stations, etc. Among the chains including hotels of this type were Best Western International, Inc. (in 1946 - Best Western Motel), Travelodge Hotels, Inc., as well as the Holiday Inns of America Corp., and Howard Johnson Co., which appeared a little later.

In this second phase of hotel chain development another interesting phenomenon can be found when along with chains oriented towards guests travelling by car, chains created by large airlines appeared. The first of this kind was Inter-Continental Hotels \& Resorts set up in 1946 and inspired by Pan American World Airways. The main characteristic typical of this sort of chain was that it usually included large high-standard hotels (4-5 star), opened in cities (often capitals or other large conurbations) and served by planes of the particular airline. This was the case with Inter-Continental Hotels \& Resorts whose first hotel, the Grande Belem, opened in 1947 in the city of that name in Brazil.

From the 1950s and '60s civil air transport developed rapidly, largely due to the fact that passenger planes were equipped with jet engines. Consequently, in the next decade airline customers were not only the wealthy but also those less well-off and this in turn led to a growing demand for accommodation in lower standard hotels. Therefore from the late 1960s hotels oriented towards aeroplane passengers increasingly provided services typical of economy hotels. This meant that they started to appear not only in the world's largest urban agglomerations (served by the major airlines), but also in smaller places often attractive to tourists, but sometimes just very 'ordinary' places with industrial and service-administrative functions.

A further very important phenomenon in the early 1950's was the appearance of hotel chains specializing in hotels for annual holidays. The first of this type was Club Mediterranée (France) whose origins go back to 1949 when Gerard Blitz organized a holiday under 
tach na Korsyce (Francja). Następne lata przyniosły gwałtowną ekspansję Club Méditerranée. Stało się tak za sprawą nie tylko umiejętnego kierowania firmą (od 1954 r. do 1993 r. na jej czele stał Gilbert Trigano), ale dopuszczenia (w 1955 r.) możliwości wnoszenia oplat za dwutygodniowy wypoczynek w 18 ratach (PAWLiNA 2003). Dzięki temu rozwiązaniu urlop w ,wiosce wakacyjnej" Club Méditerranée stał się dostępny również dla osób mniej zamożnych, co w oczywisty sposób wpłynęło na dalszy rozwój Club Méditerranée.

\section{ETAP TRZECI (LATA 1970-1990)}

Również ustalenie, kiedy skończył się etap drugi, a zaczął się etap trzeci w historii systemów hotelowych nie jest zadaniem łatwym. Mógł to być rok 1967 (otwarcie hotelu „Novotel” w Lille we Francji), rok 1968 (przejęcie istniejącego od 1939 r. Sheraton Corporation of America przez koncern telekomunikacyjny ITT, co dało początek systemowi ITT Sheraton Corp.), jak również rok 1972 (otwarcie przez Marriott Corp. pierwszego hotelu poza Stanami Zjednoczonymi). Chociaż trudno podać, kiedy zacząl się trzeci etap, to jednak można wymienić kilka zjawisk dla niego charakterystycznych.

Bardzo ważnym zjawiskiem, jakie pojawiło się w omawianym okresie, było powstawanie w ramach systemów odrębnych marek hotelowych, różniących się między sobą zazwyczaj standardem ushug (wyrażonym w liczbie gwiazdek), ceną, rodzajem lokalizacji itp. Jednym z pierwszych systemów, który wprowadził odrębną markę dla nowego rodzaju hoteli był Inter-Continental Hotels \& Resorts, W ramach którego w 1972 r. pojawiła się marka hoteli o niższym standardzie, marka nazwana Forum. $\mathrm{Z}$ czasem podobnie zaczął postępować Holiday Inns Corp., Marriott Corp. oraz S.I.E.H. Novotel.

Jednym z ważniejszych wyróżników trzeciego etapu w historii systemów hotelowych jest wyraźna ekspansja zagraniczna amerykańskich systemów, które wcześniej działały wyłącznie (lub niemal wyłącznie) we własnym kraju. Tym samym nie chodzi tu o systemy związane z liniami lotniczymi w rodzaju Inter-Continental Hotels \& ReSorts czy Hilton International Hotels, ale o takie Systemy hotelowe, jak: wspomniany Marriott Corp., Best Western (wiele znaczące jest, iż do 1974 r. nosił on nazwę Best Western Motels, a od $1981 \mathrm{r}$. Już Best Western International, Inc.) oraz Holiday Inns Corp. tents in Corsica (France) for his friends. The following years brought rapid expansion due to skilful management (between 1954 and 1993 it was run by Gilbert Trigano) and the fact that from 1955 a two-week stay could be paid for in 18 instalments (Pawlina 2003). As a consequence, taking a holiday at a Club Mediterranée 'holiday village' became available to the less well-off triggering further development.

\section{PHASE III (1970-90)}

Establishing a date when phase II finished and phase III began is not easy either. It could be 1967 - the opening of a Novotel in Lille in France, 1968 the takeover of the US Sheraton Corp. (which had existed since 1939) by ITT (a telecommunications company) to form the ITT Sheraton Corp. chain, or 1972 the opening of the first Marriott Corp. hotel outside the United States. However difficult it is to set the exact date, a number of characteristics of phase III can be listed.

The formation of individual hotel trademarks within chains was very important at this time, distinguishing between service standards (expressed by the number of stars), price, location, etc. One of the first chains to introduce a separate trademark for a new type of hotel was Inter-Continental Hotels \& Resorts with its Forum hotels of a lower standard in 1972. In time, Holiday Inns Corp., Marriott Corp. and S.I.E.H Novotel did the same.

A second important characteristic of phase III was the clear overseas expansion of American chains which had earlier operated exclusively (or almost) in the USA. This does not include airlinerelated chains such as Inter-Continental Hotels \& Resorts or Hilton International Hotels, but about such chains such as Marriott Corp., Best Western (it is worth mentioning that before 1974 it had been called Best Western Motels, and after 1981 Best Western International Inc.) and Holiday Inns Corp. 
„Ubocznym” skutkiem tej ekspansji było wyraźne wysunięcie się na czoło największych systemów hotelowych dwóch ze Stanów Zjednoczonych - Holiday Inns Corp. oraz, występującego pod różnymi nazwami, późniejszego Best Western International, Inc. - które w różnych latach na zmianę zajmowały 1. lub 2. miejsce na świecie. Jedynym nieamerykańskim systemem hotelowym, jaki znalazł się w ścisłej czołówce światowej, był brytyjski Trusthouse Forte Ltd., który w 1973 r. przejął amerykański Travelodge Hotels i w następnych latach znalazł się na 5. miejscu na świecie (KOWALCZYK 2001).

Kolejnym zjawiskiem, jakie wystapiło w trzecim etapie, było pojawienie się w Europie systemu, który zacząl mieć cechy systemu amerykańskiego i dzięki temu zaczął wykazywać podobna do niego ekspansję, systemem tym był francuski S.I.E.H. Novotel, który powstał w 1967 r. wraz z otwarciem w pobliżu lotniska w Lille (północna Francja) 3-gwiazdkowego hotelu nazwanego „Novotel" (obecnie są one na ogół hotelami 4-gwiazdkowymi). Założycielami S.I.E.H. Novotel byli Gérard F. Pélisson i Paul Dubrule, przy czym ten ostatni miał bogate doświadczenia nabyte podczas pracy w hotelach w Stanach Zjednoczonych. Prawdopodobnie dzięki temu od samego początku swojego istnienia S.I.E.H. Novotel rozwijał się w sposób przypominający rozwój systemów amerykańskich.

Z systemem S.I.E.H. Novotel - ale nie tylko wiąże się jeszcze jedno zjawisko, a mianowicie pojawienie się zachodnich systemów hotelowych W socjalistycznych krajach Europy Środkowej. W latach 1974-1975 w krótkim czasie w Polsce powstało kilka hoteli typu Novotel, co można uznać za dowód stopniowego włączania krajów socjalistycznych w światowy rynek hotelowy (jak wcześniej podano, co prawda już w latach 60 . otwarto „wioskę wakacyjną" Club Méditerranée SA w Związku Radzieckim, ale trudno ją uważać za przejaw ekspansji światowego hotelarstwa na rynek radziecki). Mniej więcej w tym samym czasie podobne działania podjął Inter-Continental Hotels \& Resorts, który uruchomil pod swoją marką dwa hotele w Polsce oraz hotel w Czechosłowacji (w Pradze).

Innym procesem, jaki można było zauważyć w tym okresie, było pojawienie się wyspecjalizowanych systemów hotelowych. Przykładem jest powstały w 1983 r. Embassy Suites Hotels, który z czasem stał się czołowym systemem na rynku hoteli apartamentowych. Podobne tendencje zaczęły
A side effect of this expansion was that two American chains - Holiday Inns Corp. and Best Western International, Inc. (which had both appeared earlier under different names) came to be the world's leading hotel chains, in various years coming either first or second globally. The only major non-American hotel chain was the British Trusthouse Forte Ltd which took over the American Travelodge Hotels in 1973 and in the following years reached fifth position (KOWALCZYK 2001).

A third characteristic which occurred in phase III was the appearance of a chain in Europe which carried some resemblance to an American chain and as a result began to expand in a similar way. This chain was the French S.I.E.H. Novotel which was set up in 1967 with a 3-star hotel (called Novotel) near the airport in Lille in northern France (at present they are usually 4-star hotels). The founders were Gerard F. Pelisson and Paul Dubrule, with the latter having gained a lot of experience in American hotels which was probably why S.I.E.H. Novotel developed in a similar way from the very beginning.

The S.I.E.H. Novotel chain is connected to the appearance of western hotel chains in the socialist countries of central Europe. In 1974-5 several hotels of the Novotel type were opened in Poland, which can be regarded as evidence of socialist countries gradually joining the global hotel market (although in the 1960s a Club Mediterranee 'holiday village' had been opened in the Soviet Union this can hardly be considered a symptom of world hotel industry expansion into the Soviet market). At more or less the same time similar activity was started by Inter-Continental Hotels \& Resorts which opened two hotels in Poland and one in Czechoslovakia (Prague).

A fourth process at that time was the appearance of specialized hotel chains such as Embassy Suites Hotels (established in 1983) which gradually became the leading chain on the suite hotels market. Similar trends can be seen regarding casino hotels, boutique hotels, etc. 
występować w segmencie hoteli kasyn gry, boutique hotels itp.

Piątym zjawiskiem, jakie pojawiło się w trzecim etapie historii systemów hotelowych, byla coraz wyraźniejsza ekspansja systemów, które zaczęły naśladować Club Méditerranée SA. Kilka z nich istniało już wcześniej (np. hiszpański RIU Hotels powstał jeszcze w 1953 r., a również hiszpański Grupo Sol, jako Hoteles Mallorquines, w 1956 r.), ale część zaczęła działać pod wpływem sukcesów Club Méditerranée SA.

Kolejnym zjawiskiem, które co prawda pojawiło się już wcześniej, jest coraz większa liczba systemów powstałych z inicjatywy linii lotniczych. Jako przykład mogą posłużyć państwowe francuskie linie lotnicze Air France (w 1972 r. powstał związany z nim Le Meridien Hotels \& Resorts) czy też British Caledonian Airways, z inicjatywy których na początku lat 70 . powstał Caledonian Hotel Holdings, w ramach którego w 1985 r. pojawiła się marka Copthorne Hotels (w 1987 r. sprzedane irlandzkim liniom lotniczym Aer Lingus). W tym czasie szybko rozwijał się również system SAS International Hotels, który powstał jeszcze w 1962 r. z inicjatywy skandynawskich linii lotniczych SAS (pierwszy należący do nich hotel - SAS Royal Hotel Copenhagen - został otwarty już w 1960 r.), które w 1980 r. uruchomily pierwszy hotel poza Europa (SAS Kuwait Hotel).

Okres 1970-1990 przyniósł również początki powstawania dużych - aczkolwiek niemogących równać się skalą z systemami amerykańskimi systemów hotelowych w Azji Wschodniej. Część $\mathrm{z}$ nich była związana z liniami lotniczymi (np. powstały w 1970 r. japoński JAL Hotels Corp., późniejszy Nikko Hotels International, czy również japoński ANA Hotels International), inne zaś z silnymi grupami przemysłowo-finansowymi z Hongkongu i Singapuru. Jako przykład może posłużyć obecny system Shangri-La Hotels International, który został zarejestrowany w $1983 \mathrm{r.}^{4}$ (KowALCZYK 2006).

Pod koniec omawianego okresu można było zauważyć jeszcze jedno zjawisko, a mianowicie coraz częstsze przejmowanie kontroli nad dużymi systemami hotelowymi przez korporacje niezajmujące się wcześniej nie tylko usługami hotelowymi, ale nawet usługami turystycznymi. Na przykład przejęcia w 1988 r. systemów Westin Hotels \& Resorts (przez japońską grupę kapitałową Aoki Corporation of Japan) i Inter-Continental Hotels \& Resorts (również przez japońską grupę finansową Seibu Saison Group), a przede wszystkim przeję-
A fifth trend was the expansion of chains following the example of Club Mediterranee. Some had existed earlier (e.g. the Spanish RIU Hotels appeared in 1953, and Grupo Sol as Hoteles Mallorquines in 1956), but others started to operate under the influence of Club Mediterranee's success.

Another sixth trend, although not new, was the growing number of chains initiated by airlines. The example of the French state airline - Air France - with Le Meridien Hotels and Resorts in 1972, or British Caledonian Airways with Caledonian Hotel Holdings in the early 1970s leading in 1985 to the Copthorne Hotels trademark which was later sold to the Irish Aer Lingus (1987). At that time there was a rapid development of the SAS International Hotels chain, which had been set up as early as 1962 on the initiative of the Scandinavian SAS airlines (their first hotel - SAS Royal Hotel Copenhagen - was opened in 1960), with their first hotel outside Europe (the SAS Kuwait Hotel) in 1980.

The period 1970-90 also saw the beginning of large hotel chains in East Asia which, however, could not be compared to those from America. Some were related to airlines, for instance the Japanese JAL Hotels Corp., established in 1970, Nikko Hotels International, or ANA Hotels International. Others were set up by powerful industrial-financial groups from Hong Kong and Singapore, for example the present Shangri-La Hotels International chain, which was registered in $1983^{4}$ (KOWALCZYK 2006).

Towards the end of the period discussed, a eighth trend could be seen, i.e. increasingly frequent takeovers of large hotel chains by corporations which had not previously been involved in hotel or even tourism services. For instance, in 1988 the Westin Hotels and Resorts were taken over by the Aoki Corporation of Japan, and the Inter-Continental Hotels and Resorts by another Japanese financial group called Seibu Saison Group. A spectacular example was the takeover of the American Holiday Inns Corp. by 
cie w latach 1989-1990 przez brytyjski koncern browarniczy Bass International Holdings Plc. amerykańskiego systemu Holiday Inns Corp.

\section{ETAP CZWARTY (LATA 1990-1996)}

O ile wyznaczenie momentu przejścia od etapu pierwszego do etapu drugiego oraz od etapu drugiego do etapu trzeciego w historii systemów hotelowych jest nie tylko subiektywne, ale i trudne, to określenie, kiedy rozpoczął się etap czwarty, jest znacznie łatwiejsze. Należy przyjać, że było to w 1990 r., gdyż w roku tym doszło do następujących wydarzeń:

- rozpoczęcia w Europie Wschodniej głębokich zmian ustrojowych, które sprawiły, iż ta część świata mogła zostać włączona do ogólnoświatowego rynku hotelowego;

- przejęcia przez Accor SA amerykańskiego systemu Motel 6 (ok. 60000 pokoi), co oznaczało nie tylko zajęcie przez system znaczącej pozycji na trudnym rynku Ameryki Północnej, ale również wejście do wąskiej grupy największych systemów świata;

- powstania w Stanach Zjednoczonych - w wyniku połączenia się Howard Johnson International, Inc. (dawniej Howard Johnson Co.) oraz części Ramada Franchise Systems - systemu składającego się wyłącznie z hoteli działających na zasadach franchisingu pod nazwą Hospitality Franchise Systems, który w roku swojego powstania znalazł się na 5. pozycji wśród największych systemów hotelowych świata; już w 1992 r. - dzięki dołączeniu Days Inn, Inc. - Hospitality Franchise Systems znalazł się na 1. miejscu wśród czołowych systemów hotelowych.

Podane wydarzenia dały początek procesowi, który można uznać za wejście systemów hotelowych na droge globalizacji nie tylko w sensie ,geograficznym" (ekspansja na coraz to nowe rynki geograficzne), ale i organizacyjnym. Dowodem na to może być fuzja Accor SA z francuską firmą Compagnié Internationale des Wagons-Lits et du Tourisme, która miała miejsce w $1991 \mathrm{r}$. W jej wyniku do Accor SA nie tylko dołączyły marki hotelowe Pullman, Etap Hotel, PLM, Altea i Arcade (system Pullman International Hotels), ale również przedsiębiorstwo dysponujące wagonami sypialnymi (Wagons-Lits), biuro podróży (Wagonlit-Travel) oraz duże sieci restauracji (Eurest i Relais Autoroute). Między innymi dzięki temu wzmocnieniu finansowemu w 1992 r. Accor SA mógł przejąć czo- the British brewery Bass International Holdings plc in 1989-90.

\section{PHASE IV (1990-6)}

If establishing the exact moments of transition from phases I to II, and from phases II to III in the history of hotel chains is difficult and subjective, stating when phase IV began is much easier. It can be presumed to have taken place in 1990, as this was the year when the following happened:

- profound political and economic changes had started in Central and Eastern Europe, which enabled this part of the world to become part of the global hotel market

- the American chain Motel 6 (c.60 000 rooms) was taken over by Accor S.A., which meant that it gained an important position on the difficult North American market and joined the small group of leading world chains

- Howard Johnson International Inc. (formerly Howard Johnson Co.) and a part of the Ramada Franchise Systems merged to form a chain consisting only of hotels based on franchising principles. It was known as Hospitality Franchise Systems, and became the fifth largest in the year it was established; in 1992, when Days Inn Inc. was added, Hospitality Franchise Systems became the leader.

These events gave rise to a process of globalization, not only in the 'geographical' sense (expansion to new geographical markets), but also organizationally. This can be seen in the merger of Accor S.A. with the French company Compagnie Internationale des wagons-Lits et du Tourisme which took place in 1991. As a result, Accor S.A. gained not only the hotel trademarks of Pullman, Etap Hotel, PLM, Altea and Arcade (the Pullman International Hotels chain), but also by the Wagons-Lits sleeping cars enterprise, a travel agency (WagonlitTravel) as well as large restaurant networks (Eurest and Relais Autoroute). Thanks to this financial reinforcement, Accor S.A. 
lowy węgierski system hotelowy (Pannonia Hotels), a w 1993 r. założył podległa mu spółkę Accor Asia Pacific Ltd.

„Ubocznym” skutkiem procesu globalizacji stały się nie tylko spektakularne sukcesy części systemów hotelowych, ale również ich porażki. Systemem, który w stosunkowo krótkim czasie zdobył bardzo wysoką pozycję na rynku, aby potem gwałtownie ją stracić (w okresie 1991-1994 pozycja 9. wśród czołowych systemów hotelowych świata, ale w 1996 r. już 14.), był brytyjski Forte Plc. (dawniej Trusthouse Forte Ltd.). Przyczyną jego szybkiego rozwoju, a potem szybkiego upadku, była gwałtowna ekspansja, która przejawiała się w przejęciu w krótkim czasie znacznej liczby luksusowych hoteli (część z nich została poddana kosztownej modernizacji) oraz francuskiego Le Meridien Hotels \& Resorts (1994 r.). „Przeinwestowanie" sprawiło, że w 1995 r. wobec Forte Plc. wszczęto postępowanie upadłościowe, a w $1996 \mathrm{r}$. większość udziałów w nim przejął brytyjski koncern Granada Group Plc. (część majątku Forte Plc. została sprzedana, np. dotychczasowa marka Forte Travelodge została przejęta przez Hospitality Franchise Systems, a z części powstał nowy system - bez porównania mniejszy - Rocco Forte Hotels).

Może nie tak spektakularne, ale również zauważalne kłopoty miały w tym okresie systemy Best Western International, Inc., ITT Sheraton Corp., a zwłaszcza Club Méditerranée SA, który jeszcze w 1990 r. zajmował 12. pozycję na świecie, w latach 1991-1994 utrzymywał się na 13. miejscu, w 1995 r. znalazł się na 14. pozycji, a w 1996 r. spadł na 18.

\section{ETAP PIĄTY (PO 1996 ROKU)}

Pojawienie się etapu piątego w historii systemów hotelowych było dosyć nieoczekiwane i jeszcze przez kilkanaście miesięcy eksperci uważali, że nowo zaobserwowane zjawiska mają charakter chwilowy (DELA CRUZ, WOLCHUK 1998, WeINSTEIN 1997). Jednak po pewnym czasie uznano, że wydarzenia mające miejsce w 1997 r. dają podstawy do przyjęcia poglądu, iż rok ten stał się początkiem nowej fazy w rozwoju światowego rynku hotelarskiego (KOWALCZYK 2001).

Tym nowym zjawiskiem, które sprawiło, że koniec lat 90. XX w. należy inaczej traktować niż ich pierwszą połowę, było pojawienie się na rynku dużych systemów hotelowych (przedtem proces ten could take over the leading Hungarian hotel chain (Pannonia Hotels) in 1992, and in 1993 established a subordinate company called Accor Asia Pacific Ltd.

The side effects of globalization were not only the spectacular successes of some hotel chains, but also the failures of others. A chain which gained a very high position over a relatively short period of time and then lost it rapidly was the British Forte plc (former Trusthouse Forte Ltd.) - in 1991-4 it was 9th among the leading hotel chains, but in 1996 only $14^{\text {th }}$. The reason of this change of fortune had been its rapid expansion, visible in the taking over of a considerable number of luxury hotels over a short time (some of them undergoing costly modernization), as well as the French Le Meridien Hotels and Resorts (1994). 'Overinvestment' led to filing for bankruptcy in 1995, and in 1996 the majority of shares were bought by the British Granada Group plc. (Part of the Forte plc. property was sold, e.g. the Forte Travelodge trademark was taken over by Hospitality Franchise Systems, and another part gave rise to a new, much smaller chain called Rocco Forte Hotels).

At that time maybe less spectacular but also noticeable problems troubled Best Western International, Inc., ITT Sheraton Corp., and especially Club Mediterranee S. A., which in 1990 was in $12^{\text {th }}$ place, in $1991-4-13^{\text {th }}$, in $1995-14^{\text {th }}$, and in 1996 fell to $18^{\text {th }}$.

\section{PHASE V (AFTER 1996)}

Phase $\mathrm{V}$ in the history of hotel chains came quite unexpectedly and for several months after it happened experts believed that the new trends were only temporary (DE LA CRUZ \& WOLCHUK 1998, WEINSTEIN 1997). However, after some time it was acknowledged that events which took place in 1997 had made this year the beginning of a new phase in the development of global hotel market (KOWALCZYK 2001).

The new trend which makes the end of the 1990s seem different to the beginning 
dotyczył tylko mniejszych systemów), tzw. REITs (od real estate investment trusts), czyli firm zajmujących się obrotem nieruchomościami i lokowaniem funduszy inwestycyjnych na rynku nieruchomości. Jednym z takich REITs, który spowodował ,wstrząs" na światowym rynku systemów hotelowych był Starwood Lodging Trust, który powstał w ramach założonej przez Barry Sternlichta (w 1991 r.) Starwood Capital Group. O ile wcześniej zajmował się on głównie przejmowaniem pojedynczych hoteli, w 1997 r. rozpoczął równocześnie starania o przejęcie ITT Sheraton Corp. (7. miejsce na świecie w 1996 r.) oraz Westin Hotels \& Resorts (17. pozycja w 1996 r.). Ponieważ działania te zakończyły się powodzeniem, w $1997 \mathrm{r}$. wśród największych systemów hotelowych świata znalazł się nowo powstały Starwood Hotels \& Resorts (na 7. miejscu).

Jednak Starwood Hotels \& Resorts nie był jedynym systemem, który powstał w inicjatywy REITs. Podobny charakter miały m.in. Patriot American Hospitality Corp., Interstate Hotels Corp. czy Richfield Hospitality Services, Inc.

Innym zjawiskiem, które nasiliło się w 1997 r. chociaż wystapiło już wcześniej - było przejęcie kilku systemów i niezależnych hoteli przez księcia Alwaleeda bin Talal bin Abdulazziz al Saud (zięcia saudyjskiego króla Fahda). Kierowany przez niego koncern Kingdom Establishment Holding Company, po wcześniejszym przejęciu pakietu kontrolnego akcji kanadyjskiego systemu Four Seasons*Regent Hotels \& Resorts, w sierpniu tego roku nabył $30 \%$ akcji szwajcarskiego łańcucha Mövenpick Hotels \& Resorts. Dzięki tym i innym transakcjom wiosną 1998 r. Kingdom Establishment Holding Company posiadała w swoich hotelach 37163 pokoje, a dalszych 1875 było w trakcie budowy (WEINSTEIN 1998).

Trzecim bardzo ważnym zjawiskiem mającym miejsce pod koniec lat $90 . \mathrm{XX}$ w. i na początku XXI w. było łączenie się systemów hotelowych. O ile wcześniej dotyczyło to głównie przejmowania mniejszych systemów przez większe, o tyle pod koniec XX w. zaczęły łączyć się systemy o podobnych rozmiarach. (Wcześniej zjawisko to wystapiło jedynie w czasie powstawania Hospitality Franchise Systems w 1990 r.).

Kolejnym doniosłym zdarzeniem $\mathrm{z}$ przełomu XX i XXI w. było znalezienie się - po raz pierwszy w historii rankingów czołowych systemów hotelowych świata - w pierwszej „20” systemu niemieckiego. Jest nim TUI Hotels \& Resorts, który po raz pierwszy zajął wysoką pozycję wśród naj- was the appearance of large hotel chains called REITs (Real Estate Investment Trusts) on the market, i.e. companies dealing in property and investing funds in the property market. Earlier this process had concerned only smaller chains. One such REIT, which caused a shock on the world hotel chain market, was Starwood Lodging Trust, set up as part of Starwood Capital Group established by Barry Sternlicht in 1991. Earlier it mainly took over single hotels, but in 1997 it attempted to take over the ITT Sheraton Corp. ( $7^{\text {th }}$ in 1996) and Westin Hotels and Resorts (17 th in 1996). As the attempt was successful, in 1997 the newly created Starwood Hotels and Resorts became the $7^{\text {th }}$ largest world hotel chain.

However, Starwood Hotels and Resorts was not the only chain brought to existence by REITs. Others included Patriot American Hospitality Corp., Interstate Hotels Corp., and Richfield Hospitality Services, Inc.

A second trend, gaining force in 1997. was the takeover of both chains and independent hotels by Prince Alwaleeda bin Talal bin Abdulazziz al Saud (the son-in-law of the Saudi King Fahd). He ran the Kingdom Establishment Holding Company which took a controlling interest in the Canadian Four Seasons Regent Hotels \& Resorts and then, in August 1997, purchased $30 \%$ of the Swiss Movenpick Hotels and Resorts shares. Due to these and other transactions, in spring 1998 the Kingdom Establishment Holding Company owned 37,163 rooms in its hotels, and further 1875 were being built (WEINSTEIN 1998).

The third very important trend at the turn of the century was the merging of hotel chains. Earlier the process had consisted in smaller chains being taken over by larger ones, but at the end of the $20^{\text {th }} \mathrm{c}$. chains of similar sizes started to combine (before, this had occurred only once when Hospitality Franchise Systems came into being in 1990).

Another important event at this time was the fact that a German chain 
większych systemów hotelowych w 1999 r. Stało się tak za sprawą przejęcia TUI w 1998 r. przez niemiecką grupę przemysłową Preussag AG. Nowy właściciel - pozbywając się posiadanych dotąd przedsiębiorstw (wśród nich ważne miejsce zajmowały elektrownie, huty i stocznie) - zacząl przejmować mniejsze systemy hotelowe (głównie z Hiszpanii, Grecji, Francji), które do tej pory wspólpracowały z TUI jako biurem podróży (DURYDIWKA, KOWALCZYK 2003). Dzięki temu już w 2000 r. nowo powstaly TUI AG/TUI Hotels \& Resorts znalazł się na 17. miejscu wśród największych systemów hotelowych świata, w 2001 r. awansował na 13. pozycję, w latach 2002-2003 oscylował wokól pozycji 14.-13., w 2004 r. znalazł się na miejscu 12., aby w 2005 r. zająć 11. pozycję (tab. 1).

Gwałtowna ekspansja TUI AG/TUI Hotels \& Resorts okazała się dalszym ciosem dla Club Méditerranée SA. O ile jeszcze w 1997 r. był on na 17. miejscu wśród czołowych systemów hotelowych świata (w stosunku do poprzedniego roku wzniósł się nawet o jedna pozycję), to w latach 1998-1999 znalazł się na 20. pozycji, w okresie 2000-2003 oscylował wokół 21.-22. miejsca, aby w 2004 r. być na 24. pozycji, a w 2005 r. spaść na 27. miejsce.

Podane zjawiska - niewątpliwie najbardziej znaczące dla obecnej sytuacji na światowym rynku systemów hotelowych - nie są oczywiście jedynymi. Jednym z nich jest rosnąca popularność systemów dysponujących tzw. boutique hotels (MYśKIEWICZ 2005). Chociaż niektóre $\mathrm{z}$ nich działały już wcześniej (np. pierwsze hotele Ian Schrager Hotels i Kimpton Group powstaly w 1981 r.), to jednak powstanie w $1998 \mathrm{r}$. w ramach Starwood Hotels \& Resorts marki W Hotels, można uznać, iż przestały one dotyczyć tylko ,niszowych” klientów. Do wysunięcia takiego wniosku upoważnia fakt, że o ile początkowo hotele butikowe interesowały klientów amerykańskich (zmęczonych „sterylnością" i monotonią tzw. chain's hotels), o tyle w ostatnich latach zaczęły one być coraz bardziej popularne w Europie i Azji.

Innym trendem, jaki pojawił się w ostatnich latach jest coraz częstsze wchodzenie na rynki Ameryki Północnej oraz Europy systemów z Azji Wschodniej oraz Azji Południowej. Jako przykład może służyć nie tylko wspomniany wcześniej Shangri-La Hotels \& Resorts, ale również systemy Z Indii, Singapuru itp. reached the top 20 for the first time in world hotel chain ranking history. The chain was TUI Hotels and Resorts which had first reached a high position in 1999 due to the takeover of TUI by a German industrial group called Preussag $A G$ in 1998. The new owner started to sell its enterprises (power stations, steelworks and dockyards) and started to buy smaller hotel chains (mainly from Spain, Greece and France) which had so far cooperated with TUI as a travel agency (DURYDIWKA \& KOWALCZYK 2003). In 2000 the new TUI AG/TUI Hotels and Resorts came $17^{\text {th }}$, in $2001-13^{\text {th }}$, in 2002 and $3-$ $14^{\text {th }}$ and $13^{\text {th }}$ respectively, in $2004-12^{\text {th }}$, and finally in $2005-11^{\text {th }}$ (table I).

The rapid expansion of TUI AG/TUI Hotels and Resorts turned out to be an additional blow to Club Mediterranee S.A. In 1997 it was still $17^{\text {th }}$ (it had even improved by one position compared to the previous year,), but in 1998-9 it dropped to $20^{\text {th }}$, in $2000-3$ to $21^{\text {st }}-22^{\text {nd }}$, in $2004-24^{\text {th }}$ and in $2005-27^{\text {th }}$.

These trends - certainly the most important for the present situation on the hotel chains world market - are not the only ones. A further one is the growing popularity of boutique hotels (MYSKIEWICZ 2005) which although they had operated earlier (e.g. the first Ian Schrager and Kimpton Group hotels appeared in 1981), the creation of $W$ Hotels in 1998 as part of Starwood Hotels and Resorts meant they were no longer reserved for 'niche' clients only. This is demonstrated by the fact that if initially boutique hotels were of interest to American clients only (tired of the 'sterility' and monotony of chain hotels), in recent years they have become increasingly popular in Europe and Asia.

Another trend in recent years is that chains from East and South Asia are increasingly frequently entering North American and European markets. The example of Shangri-La Hotels and Resorts can be quoted here, as well as chains originating from India, Singapore, etc. 
T a b e I a I. Zmiany wśród czołowych systemów hotelowych w latach 1997-2005 wg ich miejsca na liście największych systemów hotelowych świata (nazwy systemów podano $w$ wersji, jaką podano $w$ rankingu zamieszczonym w czasopiśmie Hotels w lipcu 2006 r.)

$T \mathrm{a} b \mid \mathrm{e}$ I. Changes among the leading hotel chains $1997-2005$ according to rank on the list for 2005 (Hotels magazine - July 2006)

\begin{tabular}{|c|c|c|c|c|c|c|c|c|c|}
\hline \multirow{2}{*}{$\begin{array}{c}\text { Nazwa systemu } \\
\text { Chain }\end{array}$} & \multicolumn{9}{|c|}{ Lata/Years } \\
\hline & 1997 & 1998 & 1999 & 2000 & 2001 & 2002 & 2003 & 2004 & 2005 \\
\hline InterContinental Hotels Group & 2 & 2 & 2 & 2 & 2 & 2 & 1 & 1 & 1 \\
\hline Wyndham Worldwide' & 1 & 1 & 1 & 1 & 1 & 1 & 2 & 2 & 2 \\
\hline Marriott International & 5 & 3 & 3 & 3 & 3 & 3 & 3 & 3 & 3 \\
\hline Hilton Hotels Corp. ${ }^{2}$ & 9 & 11 & 7 & 6 & 6 & 6 & 6 & 6 & 4 \\
\hline Choice Hotels International & 4 & 4 & 5 & 5 & 5 & 5 & 5 & 5 & 5 \\
\hline Accor & 6 & 6 & 4 & 4 & 4 & 4 & 4 & 4 & 6 \\
\hline Best Western International & 3 & 5 & 6 & 7 & 7 & 7 & 7 & 7 & 7 \\
\hline Starwood Hotels \& Resorts Worldwide & 7 & 7 & 8 & 8 & 8 & 8 & 8 & 8 & 8 \\
\hline Carlson Hospitality Worldwide & 10 & 9 & 9 & 9 & 9 & 9 & 9 & 10 & 9 \\
\hline Global Hyatt Corp. & 11 & 12 & 10 & 10 & 11 & 11 & 11 & 9 & 10 \\
\hline TUI AG/TUI Hotels \& Resorts & - & - & 17 & 17 & 13 & 14 & 13 & 12 & 11 \\
\hline Sol Meliá S.A. & 14 & 13 & 12 & 11 & 12 & 13 & 12 & 13 & 12 \\
\hline Extended Stay Hotels & 27 & 22 & 19 & 19 & 18 & 17 & 18 & 14 & 13 \\
\hline Interstate Hotels \& Resorts & - & - & 24 & 24 & 30 & 12 & 15 & 15 & 14 \\
\hline Société du Louvre & 18 & 17 & 13 & 15 & 14 & 15 & 14 & 16 & 15 \\
\hline Westmont Hospitality Group & 53 & 18 & 21 & 23 & 24 & 20 & 20 & 31 & 16 \\
\hline MGM Mirage & - & 81 & 86 & 37 & 33 & 36 & 44 & 42 & 17 \\
\hline Golden Tulip Hospitality/THL & - & - & - & - & 22 & 27 & 32 & 18 & 18 \\
\hline La Quinta Corp. & 20 & 19 & 18 & 21 & 19 & 19 & 19 & 17 & 19 \\
\hline Rezidor SAS Hospitality & - & - & - & - & - & 28 & 26 & 21 & 20 \\
\hline
\end{tabular}

' Do 2004 r., do czasu połączenia się z Cendant Corp., Wyndham Worldwide był samodzielnym systemem, który w rankingu przeprowadzonym w 2003 r. zajmował 16 . miejsce.

${ }^{2}$ Do 2004 r., do czasu połączenia z Hilton Hotels Corp., system Hilton Group był samodzielnym systemem, który w rankingu przeprowadzonym w 2003 r. zajmował 10. miejsce.

Ż ró d ło: Opracowano na podstawie Hotels (numery lipcowe) z lat 1998-2006.

' Until 2004, when Wyndham Worldwide merged with Cendant Corp., it was an independent chain which came $16^{\text {th }}$ in the ranking for 2003 .

2 Until 2004, when the Hilton Group joined Hilton Hotels Corp., it was an independent chain which came $10^{\text {th }}$ in the ranking for 2003 .

S o u r c e: Based on Hotels magazine (July editions) from 1998-2006.

\section{PERSPEKTYWY DALSZEGO ROZWOJU SYSTEMÓW HOTELOWYCH}

Z tego co wcześniej przedstawiono wyłania się obraz świadczący o tym, iż historia systemów hotelowych nie tylko dynamicznie rozwija się, ale również obfituje $w$ dosyć niespodziewane ${ }^{4}$ zdarzenia. Szczególne nasilenie tych nieoczekiwanych zdarzeń można było zauważyć poczynając od połowy dekady lat 90 . XX w. i na początku XXI w. Co $\mathrm{z}$ tego wynika na najbliższe lata?

Po pierwsze, można liczyć, że nadal na rynku światowym dominować będą systemy ze Stanów Zjednoczonych, aczkolwiek znaczną część udziałów w nich mogą mieć firmy $\mathrm{z}$ innych kontynentów (zwłaszcza z Azji Wschodniej, Azji Południowo-Wschodniej, Bliskiego Wschodu, a może również z Indii). Ponieważ w ostatnich latach wśród ścisłej czołówki największych systemów hotelo-

\section{HOTEL CHAINS - PROSPECTS FOR FURTHER DEVELOPMENT}

The discussion presented above shows that the history of hotel chains is not only developing dynamically but has also been full of unexpected events, especially at the turn of the new millennium. What does this mean for the future?

Firstly, it can be assumed that the world market will remain dominated by chains from the United States, although a larger proportion may belong to firms from other continents (particularly East Asia, SouthEast Asia, Middle East, and perhaps also India). As recent years however have brought a certain stability among the leading hotel chains (table I), the situation may remain unchanged in the near future. 
wych świata nastapiła pewna stabilizacja (tab. I), sytuacja taka może utrzymać się jeszcze w najbliższym czasie.

Po drugie, wielce prawdopodobne jest, iż wśród największych systemów hotelowych świata - chociaż może nie w pierwszej „10” - pojawią się nie tylko systemy z Europy, ale również z Azji. Jako pierwszy może znaleźć się wśród czołowej „20" chiński Jin Jiang International Hotels, który w roku 2005 był już na 22. pozycji pod względem liczby pokoi, a w 2004 r. zajmował jeszcze 29. miejsce. Ostatnie lata przyniosły też dosyć szybki rozwój japońskich Prince Hotels oraz JAL Hotels Co. Ltd.

Po trzecie, coraz większą rolę mogą odgrywać systemy posiadające wyspecjalizowany typ hoteli, W rodzaju boutique hotels, health and wellness hotels (SPA hotels oraz hotele połączone z beauty-farms) czy też casino hotels. Specjalizujący się w tego typu hotelach MGM Mirage zajmował w 2005 r. 17. pozycję, a Harrah's Entertainment 23. miejsce wśród czołowych systemów na świecie, przy czym rok wcześniej były one notowane odpowiednio na 42. i 52. miejscu. Wysoką pozycję mogą również zajmować systemy oferujące pobyt w resort hotels. Nieprzypadkowo w czołówce światowej utrzymują się TUI AG/TUI Hotels \& Resorts i Sol Meliá SA, a na 49. miejsce awansował w 2005 r. (aż z 75.) należący do Rewe Touristik Hotels \& Investment GMbH system LTI-International Hotels (Niemcy).

Po czwarte, należy liczyć się z dalszymi fuzjami systemów hotelowych (nawet tych dużych) oraz dalszym napływem do sektora hotelarskiego środków inwestycyjnych z firm zajmujących się dotychczas zupełnie innymi rodzajami działalności. Mogą to być banki, fundusze inwestycyjne, firmy ubezpieczeniowe, fundusze emerytalne, ale również grupy przemysłowo-finansowe, firmy handlowe, przedsiębiorstwa budowlane itd.

\section{PODSUMOWANIE}

W artykule starano się przedstawić nie tylko zmiany, jakie zaszły w części usług hotelarskich związanych $\mathrm{z}$ istnieniem systemów hotelowych, ale również zaproponować próbę ich periodyzacji. Podziału historii systemów hotelowych na etapy dokonano co prawda w sposób subiektywny, ale Opierając się na zdarzeniach o szczególnej doniosłości dla tego fragmentu rynku turystycznego. Prawdopodobnie inni autorzy przyjęliby nieco inne lata jako milestones $\mathrm{w}$ historii systemów hotelar-
Secondly, it is highly probable that this group of leading hotel chains will include not only those from Europe but also from Asia, although perhaps not in the first ten. Among the leading 20 we might see the Chinese Jin Jiang International Hotels, which in 2005 came $22^{\text {nd }}$ as regards number of rooms, while in 2004 it had been $2^{\text {th }}$. Recent years have also witnessed a quite dynamic development of Japanese Prince Hotels and JAL Hotels Co. Ltd

Thirdly, we may see a growing role for chains which include specialized types of hotel such as boutique hotels, health and wellness hotels (spa hotels and hotels combined with 'beauty farms'), or casino hotels. In 2005 MGM Mirage, specializing in this type of hotel was $17^{\text {th }}$, and Harrah's Entertainment $23^{\text {rd }}$ among the leading chains and it is worth mentioning that the year before they were $42^{\text {nd }}$ and $52^{\text {nd }}$, respectively. Chains offering stays at resort hotels may also reach a high ranking. It is not accidental that TUI AG/TUI Hotels and Resorts and Sol Melia S.A. have maintained their leading ranks, and LTIInternational Hotels (Germany), belonging to Rewe Touristik Hotels \& Investment $G M b H$, advanced from $75^{\text {th }}$ to $49^{\text {th }}$ in 2005 .

Furthermore, we should also expect further mergers of hotel chains (even large ones) and a further inflow of investment into the hotel sector from companies which were operating in completely different sectors before. These may be banks, investment funds, insurance companies and retirement funds, as well as industrialfinancial groups, commercial companies, construction firms, etc.

\section{CONCLUSIONS}

The author has attempted to present the changes which have taken place in that part of hotel services related to hotel chains, as well as to suggest a way of allocating them to separate periods. Although the division of hotel chain history into phases has been made subjectively, it has been based on events essential for this part of the tourism market. It is likely that other authors will 
skich, ale takie wydarzenia, jak otwarcie hotelu w Buffalo przez Elswortha M. Statlera, otwarcie hotelu „Holiday Inn” w Memphis czy niemal jednoczesne przejęcie Westin Hotels \& Resorts i hoteli ITT Sheraton Corp. przez Starwood Lodging Trust są niewątpliwie punktami zwrotnymi nie tylko dla systemów hotelowych, ale również dla historii światowego hotelarstwa.

\section{PRZYPISY}

\footnotetext{
'W książce TUliBaCKIEGo (2002, s. 17) można znaleźć blędną informację, iż pierwszym hotelem C. N. Hiltona (,Mobley Hotel") byl obiekt w San Francisco, a nie w Cisco. [Pomyłka wynika zapewne stąd, iż San Francisco jest często nazywane przez Amerykanów „Cisco”.] Ten sam błąd można znaleźć w znakomitej skądinąd publikacji MILEWSKIEJ i WLODARCZYKA (2005) na s. 303 , natomiast na s. $170 \mathrm{ci}$ sami autorzy podali prawidlowo Cisco.

${ }^{2}$ Więcej informacji na temat C. N. Hiltona oraz Hilton Hotels Corp. można znaleźć w publikacjach TULIBACKIEGO (2002), MILEWSKIEJ i WLODARCZYKA (2005) oraZ KoWALCZYKA (2001).

${ }^{3}$ Innymi systemami amerykańskimi, których początki sięgają lat sprzed II wojny światowej, są np. Westin Hotels \& Resorts (1930 r.) oraz Travelodge Hotels, Inc. i były Quality Courts United (1939 r.).

${ }^{4}$ Powstal on z inicjatywy, będącego obywatelem Hongkongu, chińskiego businessmana Roberta Kuoka, który jeszcze w 1971 r. otworzył w Singapurze 5-gwiazdkowy Shangri-La Hotel Singapore (530 pokoi), a w 1978 r. założyl firmę Kuok Hotels, która była częścią Kuok Group of Companies i zajmowała się zarządzaniem pięcioma hotelami w Malezji i na Fidżi (KOWALCZYK 2006).

5 Jako przykład takiej ,niespodzianki” może służyć przejęcie ITT Sheraton Corp. przez Starwood Lodging Trust, gdyż wcześniej przez kilka miesięcy toczyly się na temat przejęcia negocjacje między koncernem ITT a Hilton Hotels Corp. Nie zostały one zakończone podpisaniem odpowiedniej umowy, gdyż Hilton Hotels Corp. był zainteresowany głównie hotelami, w których byly kasyna gry, a ITT chciało sprzedać ITT Sheraton Corp. w całości.
}

suggest other years as milestones in the history of hotel chains, but such events as the opening of the hotel in Buffalo by Ellsworth M. Statler, the opening of Holiday Inn in Memphis or the almost simultaneous takeover of the Westin Hotels and Resorts and the ITT Sheraton Corp. hotels by Starwood Lodging Trust, are certainly turning points, not only for hotel chains, but also in the history of the world hotel industry.

\section{FOOTNOTES}

1 In TULIBACKI's book (2002, p.17) false information can be found that Hilton's first hotel (Mobley Hotel) was in San Francisco and not in Cisco [the error probably results from the fact that San Francisco is often called 'Cisco' by Americans]. The same error can be found in the otherwise superb publication by MILEWSKA \& WLODARCZYK (2005) on p. 303, while on p. 170 the authors quote Cisco correctly.

2 More information about Hilton and Hilton Hotels Corp. can be found in publications by TULIBACKI (2002), MILEWSKA \& WLODARCZYK (2005) and KOWALCZYK (2001).

3 Other American chains which date back to the period before World War II are e.g. Westin Hotels \& Resorts (1930) and Travelodge Hotels, Inc., as well as the former Quality Courts United (1939).

4 It was the initiative of a Chinese businessman and citizen of Hong Kong, Robert Kuok, who opened the 5-star Shangri-la Hotel Singapore (530 rooms) in 1971. and in 1978 he set up Kuok Hotels, part of the Kuok Group of Companies which was responsible for managing five hotels in Malaysia and Fiji (KOWALCZYK 2006).

5 An example of such a surprise may be the takeover of the ITT Sheraton Corp. by Starwood Lodging Trust as. prior to that, negotiations between ITT and the Hilton Hotels Corp. had been going on for several months. They had not been concluded with an appropriate contract because Hilton Hotels Corp. was mainly interested in hotels with casinos, and ITT wanted to sell the whole of ITT Sheraton Corp.

\section{BIBLIOGRAFIA - BIBLIOGRAPHY}

Dela Cruz, T., WolchuK, S., 1998, Hotels' 325, Hotels, July, s. 48-84.

DURYDIWKA, M., KowalCZYK, A., 2003, Region turystyczny a procesy globalizacji, Turyzm, 13, 1, s. 21-42.

FormicA, S., 1996, Political risk analysis in relation to foreign direct investment: a view from the hospitality industry, Revue de Tourisme - The Tourist Review Zeitschrift für Fremdenverkehr, 51, 4, s. 15-23.

KOWALCZYK, A., 2001, Geografia hotelarstwa, Wydawnictwo Uniwersytetu Łódzkiego, Lódź.

KowALCZYK, A., 2006, East Asian hotel chains - dwarfs among giants?, Asia \& Pacific Studies, Faculty of Geography \& Regional Studies, Warsaw University, 3, s. 7-35.

MYSKIEWICZ, C., 2005, Zjawisko hoteli butikowych na rynku hotelarskim, Turystyka i Hotelarstwo, 7, s. 81-102.
Milewska, M., WlodarczyK, B., 2005, Hotelarstwo. Podstawowe wiadomości z zakresu hotelarstwa. Czẹść I. Wydawnictwo WSTH, Łódż.

PAwlina, A., 2003, Idea i rozwój wiosek wakacyjnych na przykładzie Club Méditerranée, Uniwersytet Warszawski, Wydział Geografii i Studiów Regionalnych, War" szawa, maszynopis pracy magisterskiej.

TULBвACKI, T., 2002, Miedzynarodowe systemy hotelowe. Wyższa Szkoła Hotelarstwa, Gastronomii i Turystyki w Warszawie, Warszawa.

WEINSTEIN, J., 1997, Hotel's 325. Consolidation, alliances highlight giants ranking, Hotels, July, s. 42-43.

Weinstein, J., 1998, Visionary Prince Alwaleed, Hotels Investment Outlook, April, s. 18-29. 